\title{
Effects of feeding and short-term fasting on water and electrolyte turnover in female mink (Mustela vison)
}

\author{
BY SØREN WAMBERG \\ Department of Physiology, Institute of Medical Biology, Odense University, DK-5000 Odense C, \\ Denmark
}

AND ANNE-HELENE TAUSON AND JAN ELNIF

Division of Nutrition and Production, Department of Animal Science and Animal Health. The Royal Veterinary and Agricultural University, DK-1870 Frederiksberg C, Denmark

(Received 19 December 1995-Revised 1 April 1996 - Accepted 11 April 1996)

\begin{abstract}
Daily (24 h) rates of water and electrolyte turnover were measured in a conventional balance study in ten adult female pastel mink (Mustela vison) given free access to a standard mink feed for a 1-week conditioning period, followed by a $4 \mathrm{~d}$ experimental period and a $2 \mathrm{~d}$ fasting period. Drinking water was available throughout. In addition, the completeness of urine collection and the fraction of urine collected with the faeces were determined using a new experimental technique based on $24 \mathrm{~h}$ recoveries of specific urinary markers such as tritiated $p$-aminohippuric acid $\left(\left[{ }^{3} \mathrm{H}\right] \mathrm{PAH}\right)$ or ${ }^{14} \mathrm{C}$-labelled inulin $\left(\left[{ }^{14} \mathrm{C}\right] \mathrm{IN}\right)$ continuously delivered by small Alzet ${ }^{\circledR}$ osmotic pumps implanted intraperitoneally. During feeding the mean individual percentage recovery in urine of $\left[{ }^{3} \mathrm{H}\right] \mathrm{PAH}$ released from the osmotic pumps ranged from 68 to $88 \%$ (median $78 \%$ ). The mean percentage of urinary $\left.\right|^{3} \mathrm{H} \mid \mathrm{PAH}$ recovered from faecal collections was $6 \%$ (range 3-12\%). In response to fasting the mean individual percentage recovery of $\left[{ }^{3} \mathrm{H} \mid \mathrm{PAH}\right.$ in urine ranged from 62 to $78 \%$ (median $68 \%$ ). For urinary $\left[{ }^{14} \mathrm{C}\right] \mathrm{IN}$ the mean percentage recoveries in fed and fasted animals were 79 and $63 \%$ respectively. Furthermore, during fasting, withdrawal of the supplies of dietary water caused a slight but insignificant $(P=0.17)$ increase in the daily intake of drinking water and, hence, the animals maintained their normal water balance by a dramatic reduction in urine excretion $(P<0.001)$. At the same time urinary solute excretion declined significantly $(P<0.001)$, due in part to the cessation of dietary electrolyte intake and in part to reduced formation of urea, whereas urinary osmolality decreased only moderately. The mean $24 \mathrm{~h}$ balances of $\mathrm{Na}, \mathrm{K}, \mathrm{Ca}$, $\mathrm{Mg}, \mathrm{Cl}$ and $\mathrm{P}$ were close to zero and only minor differences between the feeding and fasting periods were observed. When corrected for the measured inaccuracies in urine collection the balance data obtained in the present study represent useful reference standards for normally fed and fasted non-growing mink and, to some extent, useful guidelines for future studies in experimental animals.
\end{abstract}

Carnivores: $\left[{ }^{3} \mathrm{H}\right]-p$-aminohippuric acid: Osmotic pumps: Urine collection

In studies on animal nutrition the balance technique is commonly used as an experimental tool to assess changes in the whole-body content of macronutrients (Hegsted, 1976; Jeejeebhoy, 1986). Measurements of whole-body water, electrolyte and acid-base balance have also proved valuable for diagnostic purposes, particularly in the case of nutritional imbalances and/or metabolic disturbances (Wamberg et al. 1976, 1985, 1992a). In mammalian carnivores such as cats, ferrets (Mustela putorius furo) and mink, however, the process of urine collection is tedious, cumbersome and extremely sensitive to experimental errors due to the habit of these animals of squirting and spreading urine throughout the cage, including the corner of faecal deposits (Worden \& Waterhouse, 1957; Russo et al. 1986; Wamberg et al. 1996a). Furthermore, urination in cats has been shown to vary 
considerably in volume and time (Worden et al. 1960; Klatt et al. 1975); and for these reasons there is a general lack of reliable reference data in the literature on normal $24 \mathrm{~h}$ rates of turnover of macronutrients in carnivores. The mink is a strict carnivore and, due to its small size and availability from controlled breeding stocks, it may serve as a useful experimental model for establishing nutritional and metabolic reference standards for other species of mammalian carnivores (Wamberg et al. 1992 b, 1995; Tauson et al. 1994). Investigations may be carried out in mink on a large scale at low cost to examine the influence of experimental procedures on the accuracy and validity of reference values for $\mathrm{N}$, water, electrolyte and energy turnover in fed and fasted adult mink (Glem-Hansen, 1980; Tauson et al. 1994; Wamberg, 1994). In the present study we measured the changes in rates of turnover of water and electrolytes in conscious female mink in response to normal feed intake followed by a $2 \mathrm{~d}$ fasting period (drinking water allowed) using a new technique for assessing the completeness of urine collection in small animals, which is based on the recovery of a suitable urinary marker (e.g. radioactively labelled $p$-aminohippuric acid, $\left.\left[{ }^{3} \mathrm{H}\right] \mathrm{PAH}\right)$ continuously released by small Alzet ${ }^{\text {(3) }}$ osmotic pumps implanted intraperitoneally (Wamberg et al. 1996a).

\section{MATERIALS AND METHODS}

\section{Animals}

Ten 2-year-old non-pregnant female mink (Mustela vison) of the pastel colour type, raised at the Department of Animal Science and Animal Health, The Royal Veterinary and Agricultural University, Copenhagen, were used. The animals were plasmacytosis-free and appeared healthy when transferred to the laboratory, approximately 2 months before the mating season. They were housed in individual metabolism cages (made of stainless steel, $1^{\prime \prime} \times 1^{\prime \prime}$ mesh welded netting, modified from the design of Jørgensen \& Glem-Hansen, 1973) in a controlled environment ( $10 \mathrm{~h}$ light: $14 \mathrm{~h}$ dark cycle, temperature $14-16^{\circ}$, relative humidity $30-50 \%$ ) for a 1-week conditioning period before the balance experiment. Each morning at 11.00 hours they were given a weighed amount of conventional mink feed obtained from the local feed kitchen. The average composition of the diet is given in Table 1. Throughout the pre-experimental and experimental periods, the animals were given free access to feed and tap water, except for the $2 \mathrm{~d}$ fasting period (drinking water allowed) at the end of the study.

\section{Balance technique}

In this study the conventional balance technique, described for mink by Glem-Hansen (1980) and Elnif (1992), was improved by introducing a new technique for assessing the accuracy of urine collection in small animals (Wamberg et al. 1996a) based on repeated measurements of the recovery of well-documented urinary markers $\left(\left[{ }^{3} \mathrm{H}\right] \mathrm{PAH}\right.$ and ${ }^{14} \mathrm{C}$ labelled inulin, $\left[{ }^{14} \mathrm{C}\right] \mathrm{IN}$ ), continuously released, for a period of $7 \mathrm{~d}$, by an osmotic pump implanted into the peritoneal cavity (see later, pp. 714-715). This technique also allowed assessment of the fraction of urinary admixture to faeces by comparing the rates of ${ }^{3} \mathrm{H}$ - and ${ }^{14} \mathrm{C}$-radioactivity excreted in faecal water and urine respectively. In the pre-experimental period all the animals were studied for two consecutive $24 \mathrm{~h}$ periods before surgery (days -2 and -1 ). Following implantation of the osmotic pumps the animals were allowed to recover for the first $24 \mathrm{~h}$ period and, consequently, all material collected on day 1 was discarded. The fed animals were then studied for four consecutive $24 \mathrm{~h}$ periods (day 2 to day 5), followed by a $2 \mathrm{~d}$ fasting period (days 6 and 7) with drinking water allowed. Each $24 \mathrm{~h}$ balance period was started at 11.00 hours and all collections were quantified by weight. The animals were weighed on day 0 , day 5 and day 7 (Table 2) and feed and water 
Table 1. Average dietary composition

\begin{tabular}{lc}
\hline \hline Feed ingredient (g//g wet feed mixture)* & \\
Industrial fish and fish offal & 670 \\
Poultry offal & 110 \\
Whole blood meal & 50 \\
Cereals and potato pectin & 80 \\
Soyabean oil & 10 \\
Vitamin and mineral premix $\dagger$ & 3 \\
Water added $\ddagger$ & 77 \\
Sum & 1000 \\
Chemical composition $(\mathrm{g} / \mathrm{kg})^{*}$ & \\
Dry matter & 312 \\
Crude protein $(\mathrm{N} \times 6 \cdot 25)$ & 177 \\
Crude fat & 41 \\
Minerals (mmol/kg)* & $45 \cdot 8$ \\
Sodium & $65 \cdot 5$ \\
Potassium & $257 \cdot 9$ \\
Calcium & $20 \cdot 7$ \\
Magnesium & $35 \cdot 3$ \\
Chloride & $206 \cdot 3$ \\
Total phosphorus & $4 \cdot 62$ \\
Metabolizable energy (ME) $(\mathrm{MJ} / \mathrm{kg})^{*}$ & $56: 35: 9$ \\
Percentage distribution of ME between protein:fat:carbohydrate & \\
\hline
\end{tabular}

* Wet feed mixture 'as fed'.

$\dagger$ For details of the vitamin and mineral premix, see Wamberg et al. (1992b).

$\$$ Containing $100 \mathrm{mmol}$ acetic acid per litre as a preservative.

$\S$ Calculated according to National Research Council (1982).

Table 2. Average animal live weights of female mink (Mustela vison) during the feeding and fasting periods, and daily weight change during each period*

(Values are least squared means for ten animals)

\begin{tabular}{|c|c|c|c|c|}
\hline & Feeding & Fasting & RMSE & $\begin{array}{l}P \text { value; } \\
\text { effect of } \\
\text { period }\end{array}$ \\
\hline $\begin{array}{l}\text { Live weight }(g) \\
\text { Weight change }(g / d)\end{array}$ & $\begin{array}{c}1099 \\
1 \cdot 3\end{array}$ & $\begin{array}{l}1063 \\
-39 \cdot 7\end{array}$ & $\begin{array}{l}113 \\
9 \cdot 1\end{array}$ & $\begin{array}{l}0.25 \\
<0.001\end{array}$ \\
\hline
\end{tabular}

RMSE, root mean square error.

* For details of procedures, see p. 712 .

intake was recorded daily as described by Elnif (1992). Evaporated drinking water was accounted for by concurrent measurements of the weight change of an open water jar in the laboratory. According to previous analyses the mineral content of tap water was considered negligible.

\section{Sampling}

Feed and excreta. Feed residues and excreta were weighed daily when collected and, apart from portions used for radioactivity counting, stored at $-20^{\circ}$ until analysed. Urine was collected daily in $200 \mathrm{ml}$ polyethylene bottles suspended under the urinary funnel and containing $10 \mathrm{ml} 1 \mathrm{M}-\mathrm{H}_{2} \mathrm{SO}_{4}$, except for the final $2 \mathrm{~d}$ of the pre-experimental period, where 
the urine collected was used for measurements of urinary osmolality and density. Occasionally, the animals voided small amounts of urine during handling, which were carefully collected, using a clean putty knife, weighed and added to the collecting bottle. The daily excretions of faeces were collected in polyethylene bags, weighed, homogenized and divided in two parts, one part being stored at $-20^{\circ}$ for further analysis, whilst the other was used for faecal water determination and radioactivity counting. Each day the faecal screen and the urinary funnel were thoroughly washed with approximately $10 \mathrm{ml}$ of $10 \mathrm{~g} / 1$ anhydrous citric acid. The washings were pooled for the corresponding collection period and frozen until analysed.

Blood and plasma. On the day before anaesthesia and surgery (day -1 ), and on days $2-7$, the animals were trapped at between 10.30 and 11.30 hours, and a $2-3 \mathrm{ml}$ sample of heparinized venous blood was taken from $v$. cephalica antebrachii using the technique described by Blixenkrone-Møller et al. (1987). Plasma was separated by centrifugation (3500 rev. $/ \mathrm{min}, 5^{\circ}$ for $20 \mathrm{~min}$ ) and portions were either prepared for radioactivity counting or stored at $-20^{\circ}$ until analysed. Plasma water was determined by evaporation at $100^{\circ}$ until constant weight of $500 \mu \mathrm{l}$ samples obtained before (day -1 ) and after the termination of the experiment (day 7).

\section{Anaesthesia and surgery}

On day 0 the animals were anaesthetized by intramuscular injection of ketamine hydrochloride, $40 \mathrm{mg} / \mathrm{kg}$ (Ketaminol Vet ${ }^{\circledR}$., $50 \mathrm{mg} / \mathrm{ml}$; Veterinaria AG, Zürich, Switzerland) and midazolam hydrochloride, $2.0 \mathrm{mg} / \mathrm{kg}$ (Dormicum ${ }^{\circledR}, 5.0 \mathrm{mg} / \mathrm{ml}$; Hoffman-La Roche AG, Basle, Switzerland) (Wamberg et al. 1996b). Deep surgical anaesthesià was attained in 6-8 min and, following venous blood sampling, the animal was placed in the supine position on a water thermostat-controlled heating-pad and covered with drapes. A 2 ml osmotic pump (Alzet ${ }^{\circledR}$, model 2ML1, Alza Corp., Palo Alto, CA, USA) containing an accurately weighed amount of $\left[{ }^{3} \mathrm{H}\right] \mathrm{PAH}$ and $\left[{ }^{14} \mathrm{C}\right] \mathrm{IN}$ was implanted intraperitoneally through a $20 \mathrm{~mm}$ long midline incision. The abdominal wall was closed with sterile 3-0 silk in two layers, covered with $20 \mathrm{~g} / \mathrm{kg}$ chloramine dusting powder and sprayed with sterile wound plaster (Karex ${ }^{\circledR}$, Kruuse A/S, Marslev, Denmark). Details of the construction and function of the osmotic pumps, in vitro and in vivo, are given elsewhere (Theeuwes \& Yum, 1976; Eckenhoff et al. 1981; Anonymous, 1989; Wamberg et al. $1996 \mathrm{a})$. At the end of surgery each animal was given an analgesic injection $(0.02 \mathrm{mg} / \mathrm{kg}$ subcutaneously) of buprenorphine hydrochloride (Anorfin ${ }^{*}, 0.3 \mathrm{mg} / \mathrm{ml}$; GEA A/S, Copenhagen, Denmark) and allowed to recover on a heating pad for $2-4 \mathrm{~h}$ before it was returned to the metabolism cage.

\section{Post-mortem examination}

At the end of the study the animals were weighed and anaesthetized as described previously and a $6-8 \mathrm{ml}$ blood sample was taken by heart puncture using a heparinized $10 \mathrm{ml}$ syringe. After separation, the plasma was either used for radioactivity counting, or stored in portions at $-20^{\circ}$ for further analysis. The osmotic pumps, covered by the greater omentum, were carefully removed from the peritoneal cavity and flushed with isotonic saline $(9 \mathrm{~g} \mathrm{NaCl} / 1)$ in order to measure the radioactivity remaining in the reservoir of the pumps. The animal was then killed by exsanguination, and the kidneys excised as quickly as possible, flushed with cold isotonic saline, blotted with clean tissues, and weighed. Finally, the abdominal wall and the organs of the abdominal and thoracic cavities were examined thoroughly at the macroscopic level. All experimental procedures followed 
Danish National Legislation and the guidelines approved by the member States of the Council of Europe for the protection of vertebrate animals (Anonymous, 1986).

\section{Radioactive materials and measurements}

In five animals the osmotic pumps were filled with $2 \mathrm{ml}$ (accurately weighed) of sterile isotonic saline containing $1.85 \mathrm{MBq}$ per $\mathrm{ml}$ of $\left[{ }^{3} \mathrm{H}\right] \mathrm{PAH}$ ( $p$-aminobenzoyl-2-[ $\left.{ }^{3} \mathrm{H}\right] \mathrm{glycine}$, Amersham, code TRA 197 , specific activity $19.2 \mathrm{GBq} / \mathrm{mmol}$ ). The pumps of the remaining five animals contained saline with $1.85 \mathrm{MBq}$ of $\left[{ }^{3} \mathrm{H}\right] \mathrm{PAH}$ and $925 \mathrm{kBq}$ per $\mathrm{ml}$ of $\left[{ }^{14} \mathrm{C}\right] \mathrm{IN}$ (inulin $\left[{ }^{14} \mathrm{C}\right]$ carboxylic acid, Amersham, code CFA 399, specific activity $182 \mathrm{MBq} / \mathrm{mmol}$ ). The exact amount of fluid filled into each pump was determined by weight. According to data supplied by the manufacturer, the mean nominal rate of fluid delivery by the pumps is $10.00(\mathrm{SE} 0 \cdot 15) \mu \mathrm{l} / \mathrm{h}$. When tested in vitro with sterile isotonic saline at $39 \cdot 0^{\circ}$, which is the normal body temperature of resting mink, this batch of osmotic pumps delivered on average 9.96 (SE 0.12) $\mu \mathrm{l} / \mathrm{h}$ (n 10) (Wamberg et al. 1996a).

The radioactivity of $\left[{ }^{3} \mathrm{H}\right] \mathrm{PAH}$ and $\left[{ }^{14} \mathrm{C}\right] \mathrm{IN}$ in samples of the infusion solution, the pump flushings $(25 \mu \mathrm{l})$, plasma $(100 \mu \mathrm{l})$, urine $(50 \mu \mathrm{l})$, citric acid washings $(200 \mu \mathrm{l})$ and bleached faecal water $(100 \mu \mathrm{l})$ was determined by liquid scintillation spectrometry, using the Mark III Liquid Scintillation System (model 6880, Searle Analytical Inc., IL, USA). Plasma samples were corrected for a mean DM content of 72 (SE 1) g/ $\mathrm{kg}$, and all samples were counted in duplicate using minivials containing $3 \mathrm{ml}$ scintillation fluid (Ecoscint-A, National Diagnostics, Manville, NJ, USA). In order to reduce the effect of colour quenching, $500 \mu \mathrm{l}$ samples of the dark-coloured faecal water were bleached by addition of $50 \mu \mathrm{H}_{2} \mathrm{O}_{2}(300 \mathrm{~g} / \mathrm{l})$ as described by René $e t$ al. (1983). The samples were then left for $24 \mathrm{~h}$ for a reduction of the chemiluminescence introduced by the addition of $\mathrm{H}_{2} \mathrm{O}_{2}$. Standards were prepared by dilution $(1: 1000)$ of the stock solutions with distilled water, and chemical quenching was corrected for by the external standard channels ratio method (Knoche, 1991). The percentage recoveries of $\left[{ }^{3} \mathrm{H}\right] \mathrm{PAH}$ and $\left[{ }^{14} \mathrm{C}\right] \mathrm{IN}$ in standards added to $100 \mu 1$ samples of urine and plasma were high (range 87-110\%), but remarkably lower when added to $100 \mu \mathrm{l}$ samples of bleached faecal water (range 68-75\%), due mainly to the effects of colour-induced quenching.

\section{Analytical methods}

The DM content of pooled samples of feed and faeces was determined by evaporation at $100^{\circ}$ to constant weight, and extracts for mineral analysis were made by boiling feed and faeces in $0.7 \mathrm{M}-\mathrm{HNO}_{3}$ for $1 \mathrm{~h}$ (Wamberg et al. 1976, 1992a). Faecal water was obtained daily for counting of $\left[{ }^{3} \mathrm{H}\right] \mathrm{PAH}$ and $\left[{ }^{14} \mathrm{C}\right] \mathrm{IN}$ radioactivity by centrifugation $(3500 \mathrm{rev} . / \mathrm{min}$, $5^{\circ}$ for $20 \mathrm{~min}$ ) of portions of wet faeces. The osmolality of plasma and urine was determined by means of a vapour pressure osmometer (Wescor, model 5100B, Utah, USA). Concentrations of $\mathrm{Na}$ and $\mathrm{K}$ in plasma, urine and acid extracts of feed and faecal matter were measured by flame photometry (Instrumentation Laboratory, model 443; ILS Laboratories Scandinavia, Allerød, Denmark), and those of $\mathrm{Ca}$ and $\mathrm{Mg}$ by atomic absorption spectrophotometry (Perkin Elmer 5000; Perkin Elmer Corp., Norwalk, CT, USA). Cl was determined by potentiometric titration (Cotlove et al. 1958), using the Radiometer CMT 10 titrator (Radiometer, Copenhagen, Denmark), and total $\mathbf{P}$ by the method of Baginski et al. (1967). The chemicals used were analytical grade purchased from E. Merck, Darmstadt, Germany. All analytical measurements were performed in duplicate and the analytical error, estimated from analysis of an aqueous standard solution (Wamberg et al. 1976), was less than $4 \%$. 


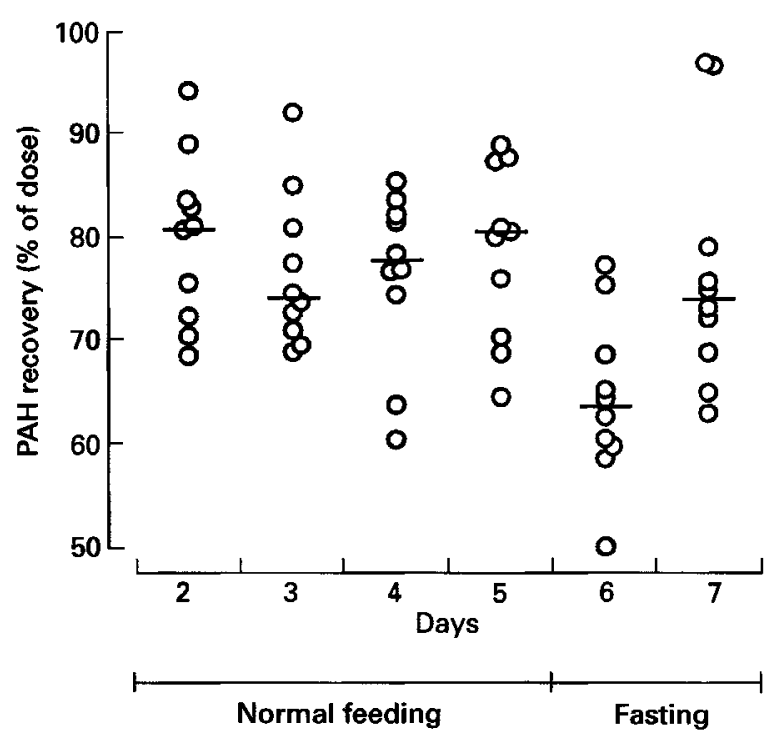

Fig. 1. Individual recoveries of $\left[{ }^{3} \mathrm{H}\right] p$-aminohippuric acid $\left(\left[{ }^{3} \mathrm{H}\right] \mathrm{PAH}\right)$ in daily collections of urine (including screen washings and urine recovered from faeces), as a percentage of the daily dose delivered by the osmotic pump, in ten female mink (Mustela vison) during normal feeding (day 2-day 5) and during fasting (days 6 and 7) (drinking water allowed). Horizontal bars indicate the median values of daily recovery of $\left[{ }^{3} \mathrm{H}\right] \mathrm{PAH}$ for ten animals. For details of procedures, see pp. 712-715.

\section{Calculations}

The individual samples of urine and faeces were analysed daily, and the former corrected to $100 \%$ PAH recovery for inaccuracies inherent in the collecting procedure, using individual values of $\left[{ }^{3} \mathrm{H}\right] \mathrm{PAH}$ recovery from urine. The total recovery of $\left[{ }^{3} \mathrm{H}\right] \mathrm{PAH}$ (and $\left[{ }^{14} \mathrm{C}\right] \mathrm{IN}$ ) was calculated as counts in daily urinary-plus-faecal water collections as a percentage of the daily dose delivered by the osmotic pumps, and the data plotted in Fig. 1. The $24 \mathrm{~h}$ urinary excretion rates of electrolytes were calculated from concentrations in non-acidified urine and the corrected $24 \mathrm{~h}$ urinary excretion. Pre-experimental collections of urine were corrected in a similar way, using the corresponding mean percentage PAH recovery obtained from urine in the feeding period. The daily osmotic load excreted by the kidneys was calculated from recorded osmolalities in urine and the corrected $24 \mathrm{~h}$ urinary volume. Electrolyte ( $\mathrm{Na}, \mathrm{K}, \mathrm{Cl}, \mathrm{Ca}, \mathrm{P}$, and $\mathrm{Mg}$ ) balances were calculated from electrolyte intake with feed, and excretion in faeces and urine, corrected to $100 \%$ PAH recovery. Rates of water turnover were calculated from individual values for the intake of drinking water and dietary water, the production of metabolic water, and the excretion of water in faeces and urine, corrected to $100 \% \mathrm{PAH}$ recovery. The DM content in urine was derived from the following regression equation:

$$
\mathrm{DM}_{\text {urine }}(\%)=7.47+0.003 \times \text { osmolality }_{\text {urine }} \text {. }
$$

This equation was derived from ninety-three observations on the urinary composition of lactating mink $\left(R^{2} 0.36 ; P<0.001\right)($ A.-H. Tauson, unpublished results). During the feeding period, calculations of metabolic water were based on feed intake and dietary composition data (Table 1), assuming that all digested nutrients were oxidized and that $23.9,28.7$ and $33.4 \mathrm{~g}$ water was produced per MJ oxidized protein, fat and carbohydrate respectively (Houpt, 1993). For the fasting period it was assumed that the animals oxidized $500 \mathrm{~kJ} / \mathrm{kg}^{0.75}$, which is close to the requirement of metabolizable energy for maintenance, 
Table 3. Feed consumption, uncorrected urine excretion, urinary osmolality and electrolyte concentrations in urine of female mink (Mustela vison) during feeding, before and after implantation of osmotic pumps, and during fasting*

(Values are period means for ten animals)

\begin{tabular}{|c|c|c|c|c|}
\hline & \multicolumn{3}{|c|}{ Period } & \multirow{3}{*}{$\begin{array}{c}P \text { value; } \\
\text { effect of } \\
\text { period }\end{array}$} \\
\hline & \multicolumn{2}{|c|}{ Feeding } & \multirow[b]{2}{*}{ Fasting } & \\
\hline & $\begin{array}{c}\text { Before } \\
\text { implantation }\end{array}$ & $\begin{array}{c}\text { After } \\
\text { implantation }\end{array}$ & & \\
\hline Feed consumption $(\mathrm{g} / 24 \mathrm{~h})$ & $175^{\mathrm{a}}$ & $160^{\mathrm{a}}$ & $0^{\mathrm{b}}$ & $<0.001$ \\
\hline Uncorrected urine excretion $(\mathrm{g} / 24 \mathrm{~h})$ & $63^{a}$ & $72^{\mathrm{a}}$ & $18^{\mathrm{b}}$ & $<0.001$ \\
\hline Urinary osmolality $\left(\mathrm{mOsm} / \mathrm{kg} \mathrm{H}_{2} \mathrm{O}\right.$ ) & $1919^{a}$ & $1897^{a}$ & $1490^{\mathrm{b}}$ & $<0 \cdot 01$ \\
\hline \multicolumn{5}{|l|}{ Urinary concentration of } \\
\hline $\mathrm{Na}(\mathrm{mmol} / \mathrm{l})$ & $26 \cdot 5^{a}$ & $20 \cdot 4^{a}$ & $12 \cdot 3^{b}$ & $<0 \cdot 001$ \\
\hline $\mathrm{K}(\mathrm{mmol} / \mathrm{l})$ & $105 \cdot 4^{\mathrm{a}}$ & $81 \cdot 5^{b}$ & $50 \cdot 2^{c}$ & $<0-001$ \\
\hline $\mathrm{Cl}(\mathrm{mmol} / \mathrm{l})$ & $61 \cdot 6^{\mathrm{a}}$ & $48 \cdot 5^{b}$ & $18 \cdot 8^{c}$ & $<0.001$ \\
\hline $\mathrm{Ca}(\mathrm{mmol} / \mathrm{l})$ & $2 \cdot 8^{\mathrm{a}}$ & $2 \cdot 3^{a}$ & $1 \cdot 4^{\mathrm{b}}$ & $<0.001$ \\
\hline $\mathrm{P}(\mathrm{mmol} / \mathrm{l})$ & $63 \cdot 7^{\mathrm{a}}$ & $51 \cdot 3^{\mathrm{b}}$ & $52 \cdot 2^{\mathrm{b}}$ & 0.03 \\
\hline $\mathrm{Mg}(\mathrm{mmol} / \mathrm{l})$ & $4 \cdot 4$ & $4 \cdot 9$ & $4 \cdot 1$ & 0.29 \\
\hline
\end{tabular}

$\mathrm{a}, \mathrm{b}, \mathrm{c}$ Mean values within a row not sharing a common superscript letter were significantly different, $P<0.05$.

* For details of procedures, see pp. 712-717.

$\mathrm{ME}_{\mathrm{m}}$ (Chwalibog et al. 1980), and that only fat was oxidized. Hence, the balance component in these calculations represents evaporative losses of water, mainly due to respiration (Wamberg, 1994).

\section{Statistical methods}

Period means for individual animals were used for further statistical analysis. For parameters derived from data which were collected before as well as after surgery in fed animals, and for fasted animals, ANOVA for repeated measures with the GreenhouseGeisser correction was employed for the evaluation of period effects. For other variables given in Tables 2-4, ANOVA regarding effect of period was performed. The statistical analyses were carried out by means of the general linear models (GLM) procedure in Statistical Analysis Systems (1985).

\section{RESULTS}

\section{Animal performance}

The animals recovered quickly from anaesthesia, and rates of feed and water intake and urinary excretion returned to pre-experimental levels within the first $24 \mathrm{~h}$ after surgery (Table 3). In the feeding period the animals maintained their body mass, but they lost weight rapidly during fasting (Table 2 ). At the post-mortem examination on day 7 , a few local scars of wound healing were seen, but there were no pathological changes in the carcasses or in the organs. The kidneys were macroscopically normal with normal wet weight and cut surfaces.

\section{Recovery of urinary markers}

The mean and individual recoveries of $\left[{ }^{3} \mathrm{H}\right] \mathrm{PAH}$ and $\left[{ }^{14} \mathrm{C}\right] \mathrm{IN}$ during the experimental periods showed a significant decrease during fasting (Tables 4 and 5). This is also demonstrated in Fig. 1, which shows individual values for the recovery of $\left[{ }^{3} \mathrm{H}\right] \mathrm{PAH}$ in 
Table 4. Recovery of $\left[{ }^{3} \mathrm{H}\right] \mathrm{p}$-aminohippuric acid $\left(\left[{ }^{3} \mathrm{H}\right] \mathrm{PAH} ; \mathrm{n} 10\right)$ and $\left[{ }^{14} \mathrm{C}\right]$ inulin $(\mathrm{n} 5)$ in fed and fasted female mink (Mustela vison) with implanted osmotic pumps, corrected amount of urine excreted, urinary osmotic load and electrolyte balance data corrected to $100 \%$ $\left[{ }^{3} \mathrm{H}\right] \mathrm{PAH}$ recovery*

(Values are least squared means)

\begin{tabular}{|c|c|c|c|c|}
\hline & \multicolumn{2}{|c|}{ Period } & \multirow[b]{2}{*}{ RMSE } & \multirow{2}{*}{$\begin{array}{l}P \text { value; } \\
\text { effect of } \\
\text { period }\end{array}$} \\
\hline & Feeding & Fasting & & \\
\hline \multicolumn{5}{|l|}{ Recovery (\%) } \\
\hline$\left[{ }^{3} \mathrm{H}\right] \mathrm{PAH}$, in urine & $71 \cdot 6$ & $70 \cdot 3$ & $6 \cdot 4$ & $0-65$ \\
\hline$\left[{ }^{3} \mathrm{H}\right] \mathrm{PAH}$, in faeces & $6 \cdot 2$ & 0 & & \\
\hline$\left.{ }^{14} \mathrm{C}\right]$ inulin, in urine & $70 \cdot 4$ & $62 \cdot 7$ & $4 \cdot 8$ & $0 \cdot 03$ \\
\hline Corrected urine excretion $(\mathrm{g} / 24 \mathrm{~h})$ & 94 & 25 & $25 \cdot 3$ & $<0.001$ \\
\hline Osmotic load $\dagger(\mathrm{mOsm} / 24 \mathrm{~h})$ & 205 & 38 & $38 \cdot 5$ & $<0-001$ \\
\hline \multicolumn{5}{|l|}{ Electrolyte balances (mmol $/ 24 \mathrm{~h})$} \\
\hline $\mathrm{Na}$ & -0.52 & -0.47 & 0.53 & $0 \cdot 86$ \\
\hline $\mathrm{K}$ & $-1 \cdot 49$ & -1.92 & $1 \cdot 14$ & $0 \cdot 41$ \\
\hline $\mathrm{Cl}$ & $-1 \cdot 45$ & -0.72 & 0.65 & $0 \cdot 02$ \\
\hline $\mathrm{Ca}$ & $0 \cdot 18$ & -0.05 & 2.07 & $0 \cdot 80$ \\
\hline $\mathrm{P}$ & -0.47 & -2.02 & 1.94 & $0 \cdot 09$ \\
\hline $\mathrm{Mg}$ & 0.03 & -0.16 & $0 \cdot 15$ & 0.01 \\
\hline
\end{tabular}

RMSE, root mean square error.

* For details of procedures, see pp. 712-717.

$\dagger$ Calculated as total urinary solute excretion.

Table 5. Mean individual percentage recovery of $\left[{ }^{3} \mathrm{H}\right] \mathrm{p}$-aminohippuric acid $\left(\left[{ }^{3} H\right] P A H\right)$, during feeding (days 2-5) and fasting (days 6-7) in female mink (Mustela vison)*

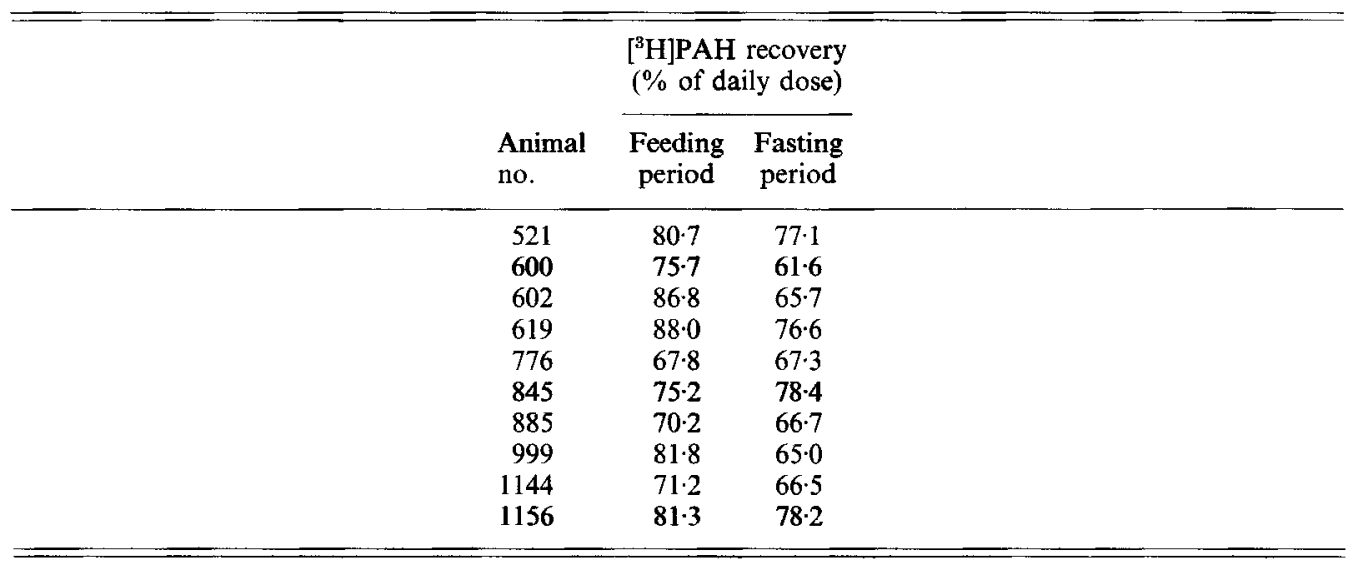

* For details of procedures, see pp. 716-717.

(total) urine, as a percentage of the daily dose, during the feeding and fasting periods. The mean percentage recovery of $\left[{ }^{3} \mathrm{H}\right] \mathrm{PAH}$ in faecal water was 6.2 (SE 0.4) \% (range $2.9-11.9 \%$ ) of the total amount of $\left[{ }^{3} \mathrm{H}\right] \mathrm{PAH}$ released during the feeding period (Table 4), indicating a moderate but rather variable contamination of faeces with urine. 


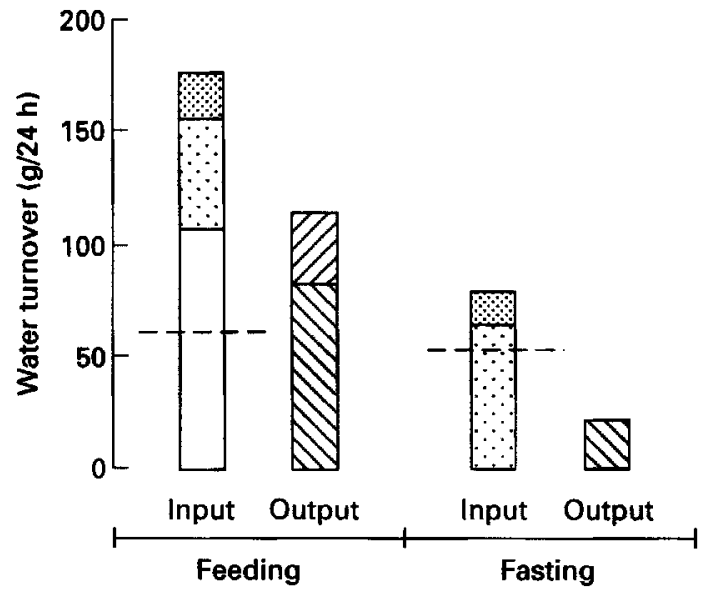

Fig. 2. Water turnover (g/d) in ten female mink (Mustela vison) during normal feeding (experimental days 4 and 5) and short-term fasting (days 6 and 7). Water output in urine was corrected to $100 \% p$-aminohippuric acid recovery. Results are presented as period means. ( $\square$ ), Dietary water; ( $\mathrm{Q}$ ), drinking water; (圈), metabolic water; $(\Theta)$, urinary water; $(\square)$, faecal water. Broken lines indicate water balance. The following $P$ values between fed and fasted animals were found: drinking water intake $(49 v .65 \mathrm{~g} / \mathrm{d}) P=0 \cdot 17$, metabolic water $(21 \mathrm{v} .15 \mathrm{~g} / \mathrm{d})$ $P=0.02$, urinary water $(81 v .58 \mathrm{~g} / \mathrm{d}) P<0.001$, and water balance $(63 v .58 \mathrm{~g} / \mathrm{d}) P=0.64$. During feeding the mean dietary water intake was $110 \mathrm{~g} / \mathrm{d}$ and the mean faecal water output $32 \mathrm{~g} / \mathrm{d}$. For details of procedures, see pp. $712-717$.

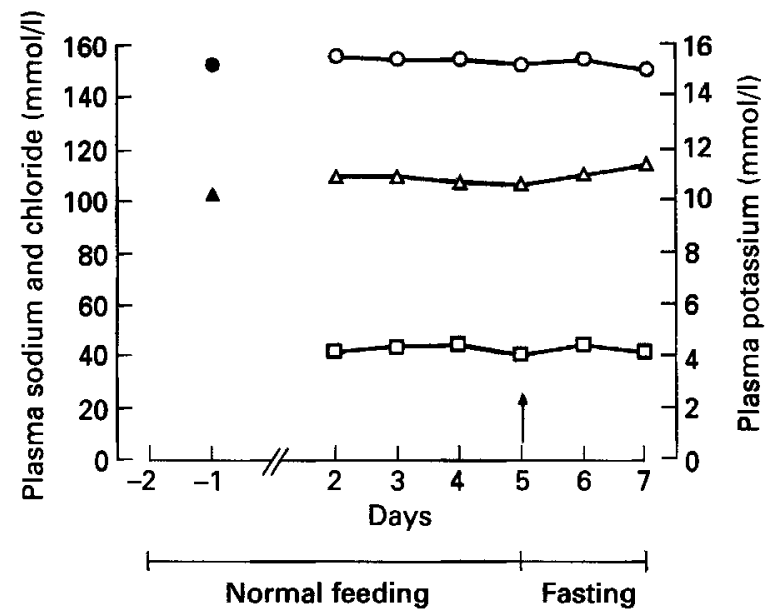

Fig. 3. Concentrations in plasma (mmol/l) of sodium $(O)$, chloride $(\triangle)$ and potassium $(\square)$ in ten female mink (Mustela vison) during normal feeding (pre-experimental day -1 ; and experimental days 2-5) and short-term fasting (days 6-7). Arrow indicates the onset of fasting. Values are means with their standard errors represented by vertical bars. Note that the error bars are hidden by the symbols. The animals had the osmotic pump implanted on day zero. No collections were made on day 1. For details of procedures, see pp. 714-715.

\section{Water and electrolytes}

The effects of feeding and fasting on whole-body water balance are shown in Fig. 2. In the fed animals, dietary water intake accounted for approximately $70 \%$ of total daily water intake. Throughout the study the plasma concentrations of $\mathrm{Na}, \mathrm{K}$ and $\mathrm{Cl}$ (Fig. 3) remained stable and within normal ranges, whereas the mean rates of urinary electrolyte excretion (Fig. 5) reflected current levels of dietary intake after surgery. During the fasting period, 


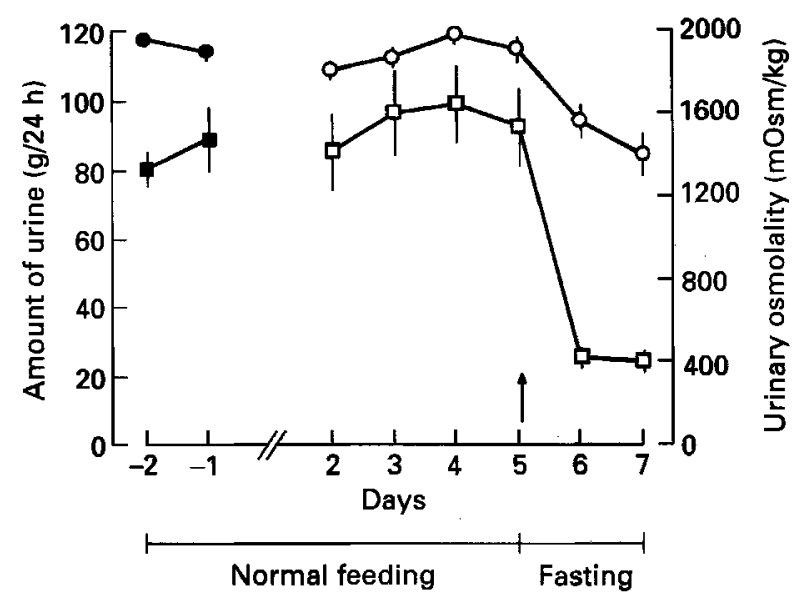

Fig. 4. Daily urinary output $(\square)(\mathrm{g} / 24 \mathrm{~h})$, corrected to $100 \% p$-aminohippuric acid recovery, and urinary osmolality $(\mathrm{O})\left(\mathrm{mOsm} / \mathrm{kg} \mathrm{H}_{2} \mathrm{O}\right)$ in ten female mink (Mustela vison) during normal feeding (pre-experimental days -2 and -1 ; and experimental days $2-5$ ) and short-term fasting (days $6-7$ ). The arrow indicates the onset of fasting. Values are means with their standard errors represented by vertical bars. Note that the animals had the osmotic pump implanted on day zero, and that no collections were made on day 1. For details of procedures, see pp. 713-716.

however, remarkable changes occurred in feed and drinking water intake, the amount of urine excreted, urinary osmolality, and urinary concentrations and excretion rates of electrolytes (Tables 3 and 4, and Figs 4 and 5). Thus, in response to the cessation of dietary water uptake during fasting (Fig. 2), drinking water intake increased, but insignificantly, whereas urine excretion declined significantly and the water balance remained unchanged. Similarly, during fasting, urinary osmolality decreased significantly and so did the total osmotic solute load presented for renal excretion (Table 4). Furthermore, in response to fasting the animals lost weight (Table 2), but the mean daily balances of electrolytes (Table 4) were only slightly negative, almost close to zero during both experimental periods. Hence, apart from $\mathrm{Mg}$ and $\mathrm{Cl}$ the balances were not significantly different between the feeding and fasting periods. Moreover, $\mathrm{Ca}$ balances were not significantly different from zero, which was also the case for the balances of $\mathrm{Mg}$ and $\mathrm{P}$ in the feeding period.

\section{DISCUSSION}

\section{Balance studies}

In the present study the animals returned to normal behaviour within $24 \mathrm{~h}$ of surgery. This was clearly documented by the rapid restoration of normal feed and water intake as well as the normal rates of faecal and urinary excretion, with electrolyte concentrations similar to those found in the pre-operation period. These observations, and the absence of pathological changes at the post-mortem examination, are taken to indicate that the experimental procedures did not have any unexpected or unfavourable effects on the animals at any point of the study.

In nutritional studies of experimental animals by the conventional balance technique, a detailed description of the construction of the metabolism cages is often included (Worden \& Waterhouse, 1957; Sinclair \& Evans, 1962; Klatt et al. 1975; Wamberg et al. 1976; Glem-Hansen, 1980). Studies to assess the accuracy of quantitative urine collection in small experimental mammals have, however, only been reported recently (Elnif, 1992; Wamberg et al. 1996a). Moreover, in metabolic studies, particularly in cats, some animals often have to be excluded from the study because of repeated episodes of incomplete urine collection 


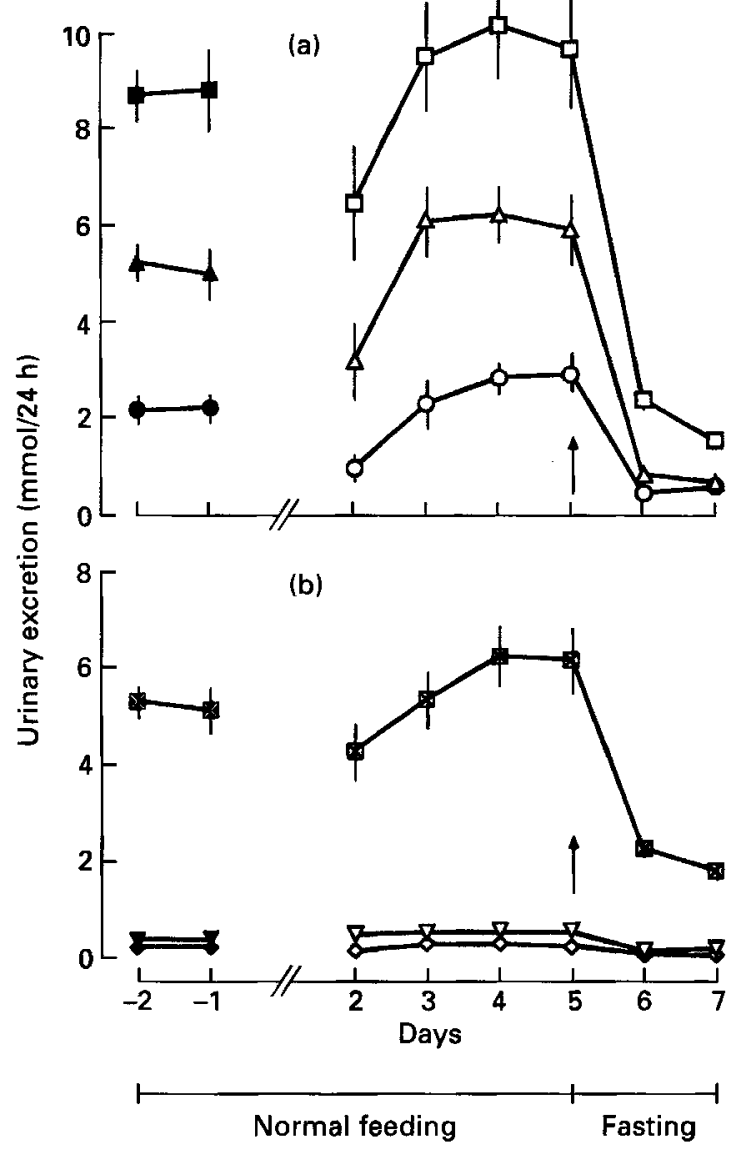

Fig. 5. Daily urinary excretion $(\mathrm{mmol} / 24 \mathrm{~h}$ ) of (a) potassium $(\square)$, chloride $(\triangle)$, and sodium $(O)$; and (b) phosphorus $(\otimes)$, magnesium $(\nabla)$ and calcium $(\diamond)$, corrected to $100 \%$ p-aminohippuric acid recovery, in ten female mink (Mustela vison) during normal feeding (pre-experimental days -2 and -1 ; and experimental days 2-5) and short-term fasting (days 6-7). Arrows indicate the onset of fasting. Values are means with their standard errors represented by vertical bars. Note that the animals had the osmotic pump implanted on day zero, and that no collections were made on day 1 . For details of procedures, see pp. 713-716.

due either to squirting or to oliguria or complete anuria during one or more collection periods (Worden et al. 1960; Klatt et al. 1975; Russo et al. 1986; Adams et al. 1991).

\section{Accuracy of urine collection}

In the present study the mean overall percentage recovery of $\left[{ }^{3} \mathrm{H}\right] \mathrm{PAH}$ in urine and faecal water during the $4 \mathrm{~d}$ feeding period was estimated to be close to $78 \%$ (Table 4 ). During fasting, however, the fractional recoveries of urinary $\left[{ }^{3} \mathrm{H}\right]$ and $\left[{ }^{14} \mathrm{C}\right]$ were significantly lower, indicating a somewhat lower efficiency of urine collection. This was mainly due to the marked reduction in daily urinary output, which, in turn, was explained by withdrawal of the normal dietary water intake and by less water being needed for the excretion of urea. In the feeding period the fraction of urine lost with the daily collection of faeces, calculated from the fraction of $\left[{ }^{3} \mathrm{H}\right] \mathrm{PAH}$ radioactivity recovered in faecal water, can be taken as a rough measure of the contamination of faeces with urine, which varied considerably, depending on the behaviour of the animals. PAH and related substances, such as para- 
Table 6. Literature data on uncorrected $24 h$ urinary volumes obtained in conventional balance studies with cats, ferrets (Mustela putorius furo) and mink (Mustela vison)

\begin{tabular}{|c|c|c|c|c|c|}
\hline \multirow[b]{2}{*}{ Author(s) } & \multirow{2}{*}{$\begin{array}{l}\text { Animal } \\
\text { species }\end{array}$} & \multirow[b]{2}{*}{ No. of animals } & \multicolumn{3}{|c|}{$\begin{array}{l}\text { Urinary volume } \\
(\mathrm{ml} / \mathrm{kg} \text { per } 24 \mathrm{~h})^{*}\end{array}$} \\
\hline & & & Mean & SE & Range \\
\hline Worden et al. (1960) & Cats & 16 & 29 & 2 & $15-44$ \\
\hline Hamlin \& Tashjian (1964) & Cats & 10 & 22 & 3 & ND \\
\hline Klatt et al. (1975) & Cats & 4 females, fasted & 44 & 6 & ND \\
\hline \multirow[t]{2}{*}{ Thornton et al. (1979) } & Ferrets & 40 males & 26 & & $8-48$ \\
\hline & & 24 females & 28 & & $8-140$ \\
\hline Esteves et al. (1994) & Ferrets & 13 ferrets, fed & 38 & 6 & ND \\
\hline \multirow{2}{*}{ Müller-Peddinghaus et al. (1979) } & Mink & 3 males, fasted & 25 & 3 & $14-28$ \\
\hline & & 3 females, fasted & 22 & 3 & $13-25$ \\
\hline Sorfleet \& Chavez (1980) & Mink & 7 males, fed & 44 & 5 & ND \\
\hline Eriksson et al. (1984) & Mink & 4 males, fed & 44 & 7 & ND \\
\hline Neil (1988) & Mink & 4 males, fed & 60 & & $46-82$ \\
\hline Tauson (1991) & Mink & 6 lactating females & 37 & & $20-62$ \\
\hline \multirow[t]{2}{*}{ Present study } & Mink & 10 females, fed & 72 & 8 & $30-100$ \\
\hline & & 10 females, fasted & 18 & 3 & $10-24$ \\
\hline
\end{tabular}

ND, no data.

* Assuming $1 \mathrm{~g}$ urine $=1 \mathrm{ml}$.

aminobenzoic acid, are readily absorbed from the gastrointestinal tract (Arvanitakis et al. 1978) and rapidly and effectively excreted in the urine (Russel et al. 1989), and losses due to hepatic metabolism and excretion in the bile are negligible (Abou-El-Makarem et al. 1987; Russel et al. 1989). Moreover, the mean $\left[{ }^{14} \mathrm{C}\right]:\left[{ }^{3} \mathrm{H}\right]$ counts ratio in collected urine $(0.57)$ was almost identical to that of the infusion solution in the osmotic pumps $(0.58)$, indicating that any possible storage or metabolic decomposition of the urinary markers was negligible. However, due to the inaccuracies inherent in measuring the radioactivities by liquid scintillation in dark-coloured faecal water, the contamination of faeces with urine is clearly underestimated (Wamberg et al. 1996a).

Therefore, under the experimental conditions prevailing in the present study the percentage of under-collection of the daily urine production can be estimated to be about $22 \%$ (range $12-32 \%$ ) and $30 \%$ (range $22-38 \%$ ) in fed and fasted adult female mink respectively. Until further evidence is available, these values may tentatively be used as guidelines for comparative nutritional studies in other species of experimental animals (see later).

\section{Water and electrolyte turnover}

As shown in Fig. 3, the concentrations of $\mathrm{Na}, \mathrm{K}$ and $\mathrm{Cl}$ in plasma were remarkably stable during the feeding and fasting periods, indicating that the renal control of water and electrolyte metabolism remained fully intact throughout the study. As expected, the rates of water and electrolyte turnover declined dramatically and significantly in response to fasting and the rates of urinary excretion of electrolytes clearly reflected the levels of dietary intake. Mean urinary osmolality decreased during fasting, due mainly to a significant reduction in urea formation and excretion (S. Wamberg and A.-H. Tauson, unpublished results), but individual values indicated that the concentrating ability of the kidneys was preserved to a substantial degree.

Literature data on the excretion of urine in small carnivorous mammals are presented in Table 6 . The mean uncorrected $24 \mathrm{~h}$ urinary volumes obtained in adult female mink in the 
present study, expressed per $\mathrm{kg}$ live weight, are comparable with those reported for small adult carnivores such as mink, cats and ferrets. However, the values reported are considerably lower than the corrected values obtained in the present study, suggesting inadequate collection of urine. This is further supported by the finding of rather high positive mineral balances in a long-term (6-month) study of whole-body mineral balances in adult cats (Ching et al. 1989). When corrected to about $70 \%$ efficiency in urine collection (faecal water neglected), the balance data reported by Ching et al. (1989) become more plausible and closer to zero.

The rates of water turnover obtained in the animals during the feeding period are comparable with the data published by Farrell \& Wood (1968), Eriksson et al. (1984) and Neil (1988). Assuming losses of water due to evaporation from the cages, spills, salivation, etc. to be of minor importance, the resulting water balance is a measure of the insensible water loss of the animals under the prevailing conditions. In the fasting period, during which dietary water uptake was zero, the animals were capable of maintaining a mean water balance of $58 \mathrm{~g} / \mathrm{kg}$ per $\mathrm{d}$, which was not significantly different from the corresponding value $(63 \mathrm{ml} / \mathrm{kg}$ per d) obtained in the feeding period (see Fig. 2). This was mainly due to the dramatic reduction in urinary output. In the feeding period the resulting water balance was about $16 \%$ lower than the value of $75 \mathrm{ml} / \mathrm{kg}$ per d obtained by direct calorimetry in female mink maintained at $18^{\circ}$ (Wamberg, 1994), and the value of $76 \mathrm{~g} / \mathrm{kg}^{0.75}$ for lactating females kept at about $15^{\circ}$ (A.-H. Tauson, unpublished results), and in good agreement with the evaporative losses of $64 \mathrm{~g} / \mathrm{kg}^{0 \cdot 75}$ observed by A.-H. Tauson (unpublished results) in adult male mink at $20^{\circ}$.

In the present study, reliable and reproducible data for $24 \mathrm{~h}$ urinary volume and electrolyte excretion were obtained in normal fed and fasted female mink by means of a new experimental technique for accurate urine collection, under experimental conditions fairly close to those prevailing in normal mink farming. In addition, during feeding and shortterm fasting the whole-body balances of electrolytes were close to zero, and water balance was maintained by an adequate renal response. Therefore, we recommend the balance data presented in this study being used not only for future studies in mink but also as a reference guide for comparative studies in other carnivores, e.g. ferrets and cats, and to some extent in experimental laboratory animals.

Finally, we would strongly emphasize that the use of surgical techniques in biomedical research, however useful in establishing experimental models for specific issues in physiological, pharmacological or advanced nutritional research, for obvious reasons must be restricted to a limited number of animals and handled with care according to international conventions for protection of animals used for scientific purposes.

The study was supported by The Danish Fur Breeders' Association and by The Danish Agricultural and Veterinary Research Council (grants no. 13-4905/1 and 13-4906/1). The skilled technical assistance of Inge Andersen, Lise Larsen, Annette Linde, Boye Pedersen and Merethe Stubgaard is gratefully acknowledged.

\section{REFERENCES}

Abou-El-Makarem, M. M., Millburn, P., Smith, R. L. \& Williams, R. T. (1967). Biliary excretion of foreign compounds. Benzene and its derivatives in the rat. Biochemical Journal 105, 1269-1274.

Adams, L. D., Polzin, D. J., Osborne, C. A. \& O'Brien, T. D. (1991). Comparison of fractional excretion and 24hour urinary excretion of sodium and potassium in clinically normal cats and cats with induced chronic renal failure. American Journal of Veterinary Research 52, 718-722.

Anonymous (1986). European Convention for the Protection of Vertebrate Animals Used for Experimental and other Scientific Purposes. European Treaty Series No. 123. Strasbourg: Council of Europe. 
Anonymous (1989). Alzet Osmotic Pumps. Technical Information Manual. Palo Alto, CA: Alza Corporation.

Arvanitakis, C., Longnecker, M. P. \& Folscroft, J. (1978). Characterization of $p$-aminobenzoic acid transport across the rat intestine. Journal of Laboratory and Clinical Medicine 91, 467-472.

Baginski, E. S., Foá, P. P. \& Zak, B. (1967). Microdetermination of inorganic phosphate, phospholipids, and total phosphate in biologic materials. Clinical Chemistry 13, 326-332.

Blixenkrone-Møller, M., Lund, E., Mikkelsen, G. \& Uttenthal, A. (1987). Blood collection in mink. Scandinavian Journal of Laboratory Animal Science 14, 99.

Ching, S. V., Fettman, M. J., Hamar, D. W., Nagode, L. A. \& Smith, K. R. (1989). The effect of chronic dietary acidification using ammonium chloride on acid-base and mineral metabolism in the adult cat. Journal of Nutrition 119, 902-915.

Chwalibog, A., Glem-Hansen, N., Henkel, S. \& Thorbek, G. (1980). Energy metabolism in adult mink in relation to protein-energy levels and environmental temperature. In Energy Metabolism. EAAP Publication no. 26, pp. 283-286 [L. E. Mount, editor]. London: Butterworths.

Cotlove, E., Trantham, H. V. \& Bowman, R. L. (1958). An instrument and method for automatic, rapid, accurate and sensitive titration of chloride in biologic samples. Journal of Laboratory and Clinical Medicine 51, 461-468.

Eckenhoff, B., Theeuwes, F. \& Urquhart, J. (1981). Osmotically actuated dosage forms for rate-controlled drug delivery. Pharmaceutical Technology 5, 35-44.

Elnif, J. (1992). Accuracy of nitrogen balance measurements in adult mink. Norwegian Journal of Agricultural Sciences, Supplementum 9, 254-260.

Eriksson, L., Valtonen, M. \& Mäkelä, J. (1984). Water and electrolyte balance in male mink (Mustela vison) on varying dietary $\mathrm{NaCl}$ intake. Acta Physiologica Scandinavica, Supplementum 537, 59-64.

Esteves, M. I., Marini, R. P., Ryden, E. B., Murphy, J. C. \& Fox, J. G. (1994). Estimation of glomerular filtration rate and evaluation of renal function in ferrets (Mustela putorius furo). American Journal of Veterinary Research 55, 166-172.

Farrell, D. J. \& Wood, A. J. (1968). The nutrition of the female mink (Mustela vison). III. The water requirement for maintenance. Canadian Journal of Zoology 46, 53-56.

Glem-Hansen, N. (1980). The protein requirements of mink during the growth period. I. Effect of protein intake on nitrogen balance. Acta Agriculturae Scandinavica 30, 336-344.

Hamlin, R. L. \& Tashjian, R. J. (1964). Water and electrolyte intake and output and quantity of feces in healthy cats. Veterinary Medicine/Small Animals Clinics 59, 746-747.

Hegsted, D. M. (1976). Balance studies (Editorial). Journal of Nutrition 106, 307-311.

Houpt, T. R. (1993). Water and electrolytes. In Dukes' Physiology of Domestic Animals, 11th ed., pp. 9-21 [M. J. Swenson and W. O. Reece, editors]. Ithaca and London: Cornell University Press.

Jeejeebhoy, K. N. (1986). Nutritional balance studies: indicators of human requirements or adaptive mechanisms. Journal of Nutrition 116, 2061-2063.

Jørgensen, G. \& Glem-Hansen, N. (1973). A cage designed for metabolism and nitrogen balance trials with mink Acta Agriculturae Scandinavica 23, 3-5.

Klatt, P., Muschaweck, R., Bossaller, W., Magerkurth, K. O. \& Wanderbeke, O. (1975). Method of collecting urine and comparative investigation of quantities excreted by cats and dogs after administration of furosemide. American Journal of Veterinary Research 36, 919-923.

Knoche, H. W. (1991). Radioisotopic Methods for Biological and Medical Research, pp. 187-210. Oxford: Oxford University Press.

Müller-Peddinghaus, R., Hackbarth, H., Alt, J. \& Küpper, W. (1979). Untersuchungen zur physiologischen Proteinurie des Nerzes. Vergleich von Proteinurie und Glomerulärer Filtrationsrate mit histologischen Befunden (Studies on physiological proteinuria in the mink. Comparison of proteinuria and glomerular filtration rate with histological findings). Zentralblatt für Veterinärmedizin, Rheie $A$ 26, 130-145.

National Research Council (1982). Nutrient Requirements of Mink and Foxes, 2nd revised ed. NCR Publication no. 7. Washington, DC: National Academy Press,

Neil, M. (1988). Effects of dietary energetic composition and water content on water turnover in mink. Swedish Journal of Agricultural Research 18, 135-140.

René, E., Danzinger, R. G., Hofmann, A. F. \& Nakagaki, M. (1983). Pharmacologic effect of somatostatin on bile formation in the dog. Gastroenterology 84, 120-129.

Russel, F. G. M., Wouterse, A. C. \& Van Ginneken, C. A. M. (1989). Renal clearance of substituted hippurates in the dog. II. 4-Amino-, hydroxy- and methoxy-substituted benzoylglycines. Journal of Pharmacology and Experimental Therapeutics 248, 436446.

Russo, E. A., Lees, G. E. \& Hightower, D. (1986). Evaluation of renal function in cats, using quantitative urinalysis. American Journal of Veterinary Research 47, 1308-1312.

Sinclair, D. G. \& Evans, E. V. (1962). A metabolism cage designed for use with mink. Canadian Journal of Biochemistry and Physiology 40, 1395-1399.

Sorfleet, J. L. \& Chavez, E. R. (1980). Comparative biochemical profiles in blood and urine of two strains of mink and changes associated with the incidence of wet belly disease. Canadian Journal of Physiology and Pharmacology 58, 499-503.

Statistical Analysis Systems (1985). SAS User's Guide: Statistics, 1985 ed. Cary, NC: SAS Institute Inc.

Tauson, A.-H. (1991). Factors Affecting the Water Requirement of Mink. NJF-Seminar no. 92. Uppsala, Sweden: National Laboratory for Agricultural Chemistry. 
Tauson, A.-H., Elnif, J. \& Hansen, N. E. (1994). Energy metabolism and nutrient oxidation in the pregnant mink (Mustela vison) as a model for other carnivores. Journal of Nutrition 124, 2609S-2613S.

Theeuwes, F. \& Yum, S. I. (1976). Principles of the design and operation of generic osmotic pumps for the delivery of semisolid or liquid drug formulations. Annals of Biomedical Engineering 4, 343-353.

Thornton, P. C., Wright, P. A., Sacra, P. J. \& Goodier, T. E. W. (1979). The ferret, Mustela putorius furo, as a new species in toxicology. Laboratory Animals 13, 119-124.

Wamberg, S. (1994). Rates of heat and water loss in female mink (Mustela vison) measured by direct calorimetry. Comparative Biochemistry and Physiology 107A, 451-458.

Wamberg, S., Clausen, T. N., Olesen, C. R. \& Hansen, O. (1992a). Nursing sickness in lactating mink (Mustela vison). II. Pathophysiology and changes in body fluid composition. Canadian Journal of Veterinary Research 56, 95-101.

Wamberg, S., Elnif, J. \& Tauson, A.-H. (1995). Rates of urinary water, electrolyte and nitrogen excretion in fed and fasted female mink (Mustela vison). Acta Physiologica Scandinavica 155, 28A Abstr.

Wamberg, S., Elnif, J. \& Tauson, A.-H. (1996a). Assessment of the accuracy of quantitative urine collection in mink (Mustela vison) using osmotic pumps for continuous release of p-amino-hippuric acid and inulin. Laboratory Animals 30, 267-272.

Wamberg, S., Engel, K. \& Stigsen, P. (1985). Acid-base balance in ruminating calves given sodium hydroxidetreated barley straw. British Journal of Nutrition 54, 655-667.

Wamberg, S., Kildeberg, P. \& Engel, K. (1976). Balance of net base in the rat. I. A technical approach. Biology of the Neonate 28, 160-170.

Wamberg, S., Olesen, C. R. \& Hansen, H. O. (1992 b). Influence of dietary sources of fat on lipid synthesis in mink (Mustela vison) mammary tissue. Comparative Biochemistry and Physiology 103A, 199-204.

Wamberg, S., Svendsen, P. \& Johansen, B. (1996 b). Acid-base status and cardiovascular function in mink (Mustela vison) anaesthetized with ketamine/midazolam. Laboratory Animals 30, 55-66.

Worden, A. N. \& Waterhouse, C. E. (1957). A metabolism cage for use with cats. Journal of Animal Technicians Association 8, 66-67.

Worden, A. N., Waterhouse, C. E. \& Sellwood, E. H. B. (1960). Studies on the composition of normal cat urine. Journal of Small Animal Practice 1, 11-23. 